\title{
Family Perceptions and Coping Strategies in Cases of Intersexuality: Understanding their Significance
}

\author{
Moara de Medeiros Rocha Santos \\ Tereza Cristina Cavalcanti Ferreira de Araujo \\ Universidade de Brasília (Brazil)
}

\begin{abstract}
Considering that the intersexual condition has a negative impact on the individual, their family, and society, health professionals and researchers have dedicated themselves to studying and assisting families faced with such an experience. The purpose of this study is to describe and understand the perceptions of primary caregivers regarding intersexuality and its developmental aspects. Six mothers and one grandmother of school age children were interviewed. The data indicated that living with the stigma of intersexuality can mean a permanent state of crisis within the family system. Issues such as guilt about the child's suffering and questions related to the choice of gender follow the family from the moment of diagnosis. It is suggested that the therapeutic follow-up should foster the necessary conditions for the family group to be organized as a model of competence, replacing the model of guilt.
\end{abstract}

Keywords: intersexuality, family, hermaphroditism, psychological support

\begin{abstract}
Considerando que la condición intersexual tiene un impacto negativo en el individuo, su familia y la sociedad, los profesionales e investigadores de la salud se han dedicado a estudiar y ayudar a las familias que afrontan tal experiencia. El objetivo de este estudio es describir y entender las percepciones de los cuidadores primarios con respecto a la intersexualidad y sus aspectos evolutivos. Se entrevistaron a seis madres y una abuela de niños en edad escolar. Los datos indicaron que vivir con el estigma de la intersexualidad puede significar un estado permanente de crisis en el sistema familiar. Problemas tales como la culpa por el sufrimiento del niño y las preguntas relacionadas con la elección del género acompañarán a la familia desde el momento del diagnóstico. Se sugiere que el seguimiento terapéutico promocione las condiciones para la organización del grupo familiar como modelo de competencia, reemplazando el modelo de culpabilidad.

Palabras clave: intersexualidad, familia, hermafroditismo, apoyo psicológico
\end{abstract}

Correspondence concerning this article should be addressed to Moara de Medeiros Rocha Santos, Doutora em Psicologia pela Universidade de Brasília (Brazil). E-mail: moara@unb.br or to Tereza Cristina Cavalcanti Ferreira de Araujo, Prof ${ }^{a}$ Dr $^{\mathrm{a}}$ do Instituto de Psicologia da Universidade de Brasília (Brazil). Phone: (61) 3273.0838 Fax: (61) 3349.0183. Email: araujotc@unb.br

How to cite the authors of this article: Santos, M.M.R. and Araujo, T.C.C.F. 
At the beginning of development, the embryo may develop either male or female sex, but errors in this process may result in abnormal sexual differentiation. This differentiated condition is called intersex in studies regarding the psychosocial aspects, while the terms ambiguous genitalia and hermaphroditism are principally adopted in the medical literature (Moore \& Persaud, 2000). Currently, intersexual conditions are classified according to anatomic, histological, cytological and psychiatric conditions. True hermaphroditism (TH) is defined as an extremely rare condition of incomplete gonadal differentiation, entailing the simultaneous existence of ovarian and testicular tissues in the same individual. In puberty, development of mammary tissue, menstruation and virilization may occur. Pseudo-hermaphroditism is the condition in which gonadal tissue of only one gender appear, which may be either male or female. Male pseudo-hermaphrodites (MPH) are partially masculinized males, who possess masculine genetics (46 $\mathrm{XY}$ ) and gonads with testicular tissue. The internal genitalia do not develop normally, and the external genitalia may be ambiguous or female. In both cases, TH and MPH, the individuals are sterile. In feminine pseudo-hermaphroditism (FPH), the individual has female gonads, which are generally functional, and a chromosomal constitution of 46, XX. The internal genitalia are female, however the external genitalia are ambiguous, with various degrees of masculinization (Guerra-Júnior, 2002; Maciel-Guerra \& Guerra-Júnior, 2002a-b).

In general, clinical management of intersexuality is supported in the theory of Psychosexual Neutrality at Birth and the theory of Interactionist Tendency after Birth. Proposed by Money, Hampson and Hampson (1955), the first theory proposes sexual designation up to 24 months of age, under the assumption that gender identity is still unestablished and susceptible to alteration in this period. After two years of age, any modification may cause psychological disturbances (Money, 1994a-b; Slijper, Drop, Molenaar, \& De Muinck Keizer-Schrama, 1998).

In the case of genetically masculine individuals, Money and his colleagues ensure that, if they are assigned to the male sex, they may come to suffer psychological and moral damage due to the reduced size of the penis. Although the current literature presents no consistent evidence regarding such damage, this approach recommends that infants in this condition be assigned to the female sex. Therefore, according to the Theory of Psychosexual Neutrality at Birth, for an individual to be assigned to the male sex, it is necessary to evaluate the functional and aesthetic condition of the genital organs, as well as the possibility of the individual maintaining an orthostatic position for urination. Since the perception of the child in relation to his/her own body is an important factor for consolidation of gender identity, surgical correction of the genitalia is also suggested for genetically feminine individuals (Meyer-Bahlburg, 1999; Zucker, 1999).
For preventive reasons, surgery performed in the first years of life appears to address the difficult issues regarding what medical providers should do to medical conduct. The emphasis on the urgency to operate may convey the idea that there are risks to the child's health, confusing the family; yet risk is rare. From the medical point of view, the decisions may be postponed in most cases. Careful analysis indicates that this proposal, of an interventionist nature, is becoming commonly adopted by the medical community relying on a reference point whose basis is not well understood or supported from the perspective of Developmental Psychology and Health Psychology (Santos, 2000). Ample use of this approach occurs, in part, due to the decisive and unquestionable form by which the sexual designation is made, which gives the impression that the natural and true gender of the child was finally discovered and that the problem is being managed. The proposal for early surgery is also justified to avoid difficulties for the parents in dealing with the uncertainties of the child's sexual ambiguity (Slijper et al., 1998; Zucker, 1999).

In the last thirty years, observations from professional experiences and stories from intersexual individuals from various cultures have led to criticism of the proposal from Money et al. In 1965, the Theory of Interactionist Tendency after Birth was suggested by Diamond and Sigmundson, based on clinical repercussions of unreflected adoption of practices based on the Theory of Psychosexual Neutrality at Birth. This proposal opposes the emphasis given to the first two years of life in the approach applied to this day. Diamond and Sigmundson consider communication about the intersexual condition to the parents and child important, adjusting the information according to the receptive capacities of the individuals in question. Thus, by encouraging participation of the child in the decision-making process regarding his/her treatment, the theory suggests postponing aesthetic surgery until the subject understands his/her condition (Diamond, 1996, 1997, 2006; Diamond \& Sigmundson, 1997a, 1997b; Reiner, 1997a, 1997b).

Under this focus, the decision regarding sexual assignment should not be based primarily upon the anatomical prognosis or a particular sexual function, but rather on the psychological development of the subject. Aesthetic surgery is not recommended for a child, since it is thought that the differentiated appearance of genitalia in the child causes less damage than adult genitalia that are apparently normal, but have compromised functionality and reduced erotic sensitivity. As such, it is argued that only after puberty is the patient capable of making an informed decision with respect to what is to be done to his/her body. In most cases there is still no urgency or need for surgery (Diamond, 2006; Diamond \& Sigmundson,1997b). Another aspect to be considered is the fact that the procedures involved in the model of the Theory of Psychosexual Neutrality at Birth deny the individual the option to choose his/her own identity and gender role. It is suggested, then, that physicians consider the future sexual preference of the child to be relevant and avoid performing 
any irreversible surgery (Diamond, 2004; Diamond \& Beh, 2005). Treatment for intersex cases, according to the Theory of the Interactionist Tendency after Birth, requires involvement from the time of diagnosis and treatment including followup throughout the developmental life span, above all, in relation to the psychosocial dimension. Thus, as appropriate to the development level of the individual, it is possible to implement counseling sessions involving discussion of sexuality associated with the intersexual condition, such as, for instance, the presence or absence of menstruation, fertility or infertility, adoption, contraception, options for sexual orientation and conjugal life. During puberty, surgical or hormone treatment options may be presented. If reasignment sexual surgery surgery is considered, it is recommended that the patient do a test, living for some time assuming the desired gender role prior to surgery, allowing a period of adjustment to the new social role (Diamond, 2006).

Psychological support must be continuous and must extend to the entire family, emphasizing acceptance of the child and coping with his/her condition. Psychological monitoring intended for the parents assists in the consolidation of the gender appointed to their children, thus avoiding any ambiguity of perception. It is important that the parents remain consistent with the gender in which the child is being raised, boy or girl, while still permitting free expression as far as choice of games, toys, friendships and future aspirations (Hester, 2004; Holmes, 2002).

The two proposals for the management of intersexuality, despite being contradictory in other aspects, are both focused on the moment designated for intervention as the decisive factor in the success of the process of changing gender. From the clinical point of view, the prescriptive character of both seems reductive, which can be explained by both having been produced to assist health professionals in their medical practices. Neither of the two proposals adequately discusses the problem of gender identity in light of the studies conducted by human development theorists (Santos, 2000). To understand the factors that influence the choice of a male or female identity, identifying biological and environmental factors in determination of sexual and gender behavior remains a significant challenge for psychological researchers (Santos \& Araujo, 2003).

It is important to remember that, according to Developmental Psychology theories, children behave according to their gender long before fully understanding what gender actually means (Martin, Ruble \& Szkrybalo, 2002). In the process of constructing this concept, relations within the family, especially among parents and children, exercise a fundamental role in terms of emphasizing and constructing the roles and differences between the genders (Valsiner, Branco, \& Dantas, 1997). Insofar as they select the type of activity for the child, the parents enable development of abilities differentiated between girls and boys in relation to one or another type of activity (Bussey \& Bandura, 1999).
In cases of intersexuality, generally understood as a chronic illness, it is common that interactions between the individual, the family and their social network are affected (Santos, 2000). On the other hand, such experience may encourage the building of new social networks. As with families of chronically ill patients, the families of intersex children face the loss of the "normal" life that they had prior to the diagnosis, including the loss of future life projects. A family evaluation regarding the illness should include, among other aspects, the significance of the illness for the whole family and the understanding of the methods of transferring catastrophic myths, taboos, and expectations and the family's belief system throughout generations (Walsh \& McGoldrick, 1998).

Considering, however, the scientific and professional interest in the matter, this particular study was executed in order to discover and understand the perceptions of primary caregivers regarding intersexuality and its developmental aspects.

\section{Method}

\section{Participants}

Seven individuals responsible for children with intersex diagnosis, and with no other associated pathology, participated in this study, distributed as follows: three mothers and one grandmother of Female Pseudo-Hermaphrodites (FPH), two mothers of True Hermaphrodites (TH), and one mother of a Male Pseudo-Hermaphrodite (MPH). The children ranged in age from six to ten years. The mothers had between 24 and 41 years of age (the grandmother, responsible for the child identified as M5 did not give her age). Three mothers were married (M1, M3 and M6) and three were separated (M2, M4 and M5). One of them (M4) maintained a relationship with the father of the child, who was married but provided financial support to the family. Three of the mothers had taken some form of medication during the pregnancy, including an abortificant (M3), anabolic hormones (mother of C5), and thyroid medication (M7). None of the families had a prior history of ambiguous genitalia, except for the family of M2, who had a niece with the same diagnosis as the daughter (see Table 1). The participants were recruited through data from case histories and medical records from two large hospitals in the capital of Brazil which offered treatment for intersexual conditions.

\section{Instrument}

A series of semi-structured interviews was used, created for the child's primary caregiver, which included questions regarding the diagnosis and treatment, comprehension of the problem, expectations for the future, family history of the child, as well as sexuality, identity, gender role and socialization. The interviews were audiotaped with the participant'consent. 
Table 1

Participant Characteristics

\begin{tabular}{|c|c|c|c|c|c|c|c|c|c|c|}
\hline \multicolumn{3}{|c|}{ MOTHERS } & \multicolumn{8}{|c|}{ CHILDREN } \\
\hline CAREGIVER & Age & Education & CHILD & Diagnosis & $\begin{array}{c}\text { Current } \\
\text { Age }\end{array}$ & $\begin{array}{l}\text { Age at time } \\
\text { of diagnosis }\end{array}$ & $\begin{array}{l}\text { Gender of } \\
\text { upbringing }\end{array}$ & $\begin{array}{l}\text { Type of } \\
\text { treatment }\end{array}$ & $\begin{array}{l}\text { Age at time } \\
\text { of surgery }\end{array}$ & $\begin{array}{c}\text { Education } \\
\text { level }\end{array}$ \\
\hline M1 & 24 & $4^{\text {th }}$ grade & $\mathrm{C} 1$ & FPH & $\begin{array}{l}7 \text { years, } \\
10 \text { months }\end{array}$ & 4 years & Female & $\begin{array}{c}\text { Surgery and } \\
\text { Hormones }\end{array}$ & 4 years & $1^{\text {st }}$ grade \\
\hline M2 & 30 & High school & $\mathrm{C} 2$ & FPH & $\begin{array}{l}7 \text { years, } \\
4 \text { months }\end{array}$ & at birth & Female & None & - & $1^{\text {st }}$ grade \\
\hline M3 & 40 & $4^{\text {th }}$ grade & $\mathrm{C} 3$ & FPH & $\begin{array}{l}10 \text { years, } \\
8 \text { months }\end{array}$ & at birth & Female & $\begin{array}{c}\text { Surgery and } \\
\text { Hormones }\end{array}$ & 3 years & $4^{\text {th }}$ grade \\
\hline M4 & 41 & Primary school & $\mathrm{C} 4$ & $\mathrm{TH}$ & $\begin{array}{l}6 \text { years, } \\
10 \text { months }\end{array}$ & 1 year & Male & $\begin{array}{c}\text { Surgery and } \\
\text { Hormones }\end{array}$ & $\begin{array}{l}8 \text { months, } \\
1.5,2,5, \\
\& 6 \text { years }\end{array}$ & $1^{\text {st }}$ grade \\
\hline $\begin{array}{l}\text { M5 } \\
\text { (Grandmother) }\end{array}$ & $\begin{array}{l}\text { Didn't } \\
\text { say }\end{array}$ & High school & C5 & FPH & $\begin{array}{l}8 \text { years, } \\
1 \text { month }\end{array}$ & at birth & Female & $\begin{array}{c}\text { Surgery and } \\
\text { Hormones }\end{array}$ & 1 year & $2^{\text {nd }}$ grade \\
\hline M6 & 32 & $2^{\text {nd }}$ grade & C6 & $\mathrm{TH}$ & $\begin{array}{l}6 \text { years, } \\
2 \text { months }\end{array}$ & 5 months & Male & $\begin{array}{c}\text { Surgery and } \\
\text { Hormones }\end{array}$ & $\begin{array}{l}6 \text { months, } \\
1.8 \text { years }\end{array}$ & $1^{\text {st }}$ grade \\
\hline M7 & 35 & High school & $\mathrm{C} 7$ & $\mathrm{MPH}$ & 7 years & 4 months & Female & Surgery & 1 and 2 years & $1^{\text {st }}$ grade \\
\hline
\end{tabular}

\section{Procedures}

After initial telephone contact to explain the objectives of the research and confirm the case history data, principally with respect to the diagnosis, a meeting was scheduled at the participant's home, according to each individual's availability. Before the interview, two copies of the Free and Clear Consent Form were signed by the researcher and the caregiver. The interviews were each approximately half an hour, totaling approximately 420 minutes of recorded audio.

\section{Results and Discussion}

The information acquired from the mother's stories was divided into the following categories: Diagnosis and Treatment of the Intersexual Condition, Family Trajectory, and Caregiver's Perception of the Child. The first included information regarding the knowledge and understanding of the problem, the decision for sexual designation, counseling received from doctors, and the difficulties faced in treatment. The second category included information on the family dynamics from planning of the pregnancy, such as family planning, desired gender of the child, family relationships, education, communication and interaction, emotional reaction when facing the diagnosis, difficulties with the situation, family conduct, counseling offered by the parents to the child, and expectations regarding the future and possible surgery. Finally, the category "Caregiver's Perception of the Child" gathered information about the personal and developmental characteristics of the child, such as perception of his/her own body and the bodies of other children, sexual curiosity, gender role and identity, socialization, disclosure of the situation, the child's expectations for the future, and others' perceptions of the child.

Diagnosis and treatment of the intersexual condition. With the exception of families 1 and 7 , all the other families received information from the health team immediately after the birth of the child or prior to release from the hospital. The stories from the other mothers suggest that they had a partial and fragmented conception of the intersexual condition. The mothers used lay terms such as "semihermaphroditism," "reversed sex," "undefined," and "recessed testicle" as names for the intersexual condition.

Questions regarding culturally inappropriate behavior for the child's gender, etiology and physiology of the condition, and the consequences of interrupting treatment remained even after medical explanation. The concerns that worried the mothers the most were related to the possibility of sex change, inadequacy of physical appearance and compromise of physiological functions.

The decision regarding sexual assignment was made by the medical team, with the exception of cases 1 and 7, which 
were not diagnosed at birth, and for which the parents' decision prevailed, which, in turn, was based on the opinion of the physician and social implications. According to the mothers, the responsibility for determining which gender to assign for the child's upbringing generated feelings of insecurity due to the possibility of an erroneous choice.

The teams counseling the parents focused, mainly, on secrecy in relation to the situation, as much for the child as for those outside the family. The professionals also recommended that, with the approach of surgery, the child be monitored by mental health services, as well. M1, M3, M5, and M7 confirm that they had conversed with psychologists, even in the hospital at the time of birth. The participants indicated that the physicians recommended psychological treatment for the child only.

The difficulties that they emphasized in relation to treatment were in relation to the high cost of imported drugs (such as hormones), the delay in receiving results from exams, and the medications and travel to distant hospitals to seek treatment. Above all, the greatest complaint that the participants related was in regard to the difficulty in obtaining information from the team about intersexuality. According to those interviewed, the professionals often used technical language, rather than explaining in language that the parents could understand. According to M6's perception, the doctors appeared to find the situation difficult, which would explain putting off informing and counseling the patient and family.

Family trajectory. Among the mothers, M2, M6, and M7 had planned to become pregnant. M3 and M6 indicated that they would have preferred a child of the opposite gender to form a pair with an older sibling, and the other mothers indicated not having had a preference for either gender during pregnancy.

Family relations were considered positive by the majority of the mothers. In some interviews, there were complaints, such as fighting with siblings, largely due to different ages (M2, M3, M4 and M7) and the lack of participation of the parents in upbringing or in matters related to the child's treatment, such as appointments and meetings with doctors (M6 and M7).

None of the mothers spoke of any difference in the education given the child due to the child's condition. Communication about sexual matters was approached naturally among members of the family. The children's questions were resolved as far as they asked and each mother sought to respond in a manner compatible with their child's capacity to comprehend. M1 and M3 mentioned that they did not feel comfortable speaking about sex, and, for this reason, never approached the subject with their child

Mothers M1, M2, M3, and M7 said that they told nothing to their children regarding the pathology and treatment, as they believed the child would not understand the problem, because they did not know how to approach the topic and feared the child's reaction, or because they did not want to reveal such information. Other mothers confirmed that they explained, in whole or in part, the diagnosis to the child, but that they intentionally concealed the existence of sexual organs of both genders in the body.

Most revealed nothing to other family members or friends, or revealed only "non-compromising" aspects related to hormonal problems. To justify the surgery to other persons, they gave explanations not connected to the diagnosis, such as a hernia (M7).

All of the mothers interviewed described emotional reactions of despair and uncertainty due to the diagnosis, which remained to the time of this study. The principal difficulties mentioned were associated with the initial shock caused by learning that they had a child with ambiguous genitalia. The mothers frequently mentioned feelings of disgust, nonacceptance, insecurity and disappointment. Among the greatest difficulties experienced by the family, dealing with social preconceptions was the most harmful experience related and this was reflected in the family relations.

It was observed that the parent responsible for the child's treatment generally felt overwhelmed, owing to the redistribution of roles or their strategy of coping with the matter. Not knowing how to deal with the difficulties presented by the child's condition, the caregiver may choose to leave decisions and the continuity of therapy under the responsibility of the doctors or the other parent. Strategies of coping with the situation used by the families included: (a) adoption of a "gender neutral" name until the decision for gender assignment is resolved (M4); (b) attitudes of protection of the child against comments from others, motivating the child to not expose their body (M6); (c) raising the child without ambiguity, considering the assigned gender as definitive (M4); (d) permission for the child to express ideas and behaviors freely, without imposition from the parents (M7); and (e) active participation in the treatment, not allowing all the decisions to be made by the doctors alone (M7). Other parents assumed a posture of discipline and punishment towards behaviors that they considered inappropriate for the child's gender, reflecting non-acceptance of the diagnosis (M2, M3, and M5).

They also spoke of counseling their children regarding how to behave in situations that may provoke comments and criticism from other people, such as that the child only go to the bathroom alone, and not undress in the presence of others. The parents also worried about preparing answers for "embarrassing" questions, attempting to assist the child to prepare for confrontations with other children.

The mother's expectations for their child's future were optimistic with respect to research and the medical profession, and the results of the surgery. In some cases the parents refrained from projecting future plans for the child, due to uncertainties regarding the possibility that the child may choose the opposite gender (M2 and M4). These same mothers also referred to feelings of suffering for knowing of the child's limitations due to their condition. 
Caregiver's perception of the child. According to the participants' evaluations, the children were calm and happy. Overall, aggression, nervousness and agitation were also characteristics acknowledged ( $\mathrm{C} 1, \mathrm{C} 2$ and $\mathrm{C} 3$ ), which may be less evident after hormonal treatment. Only C6 was described as being timid or introverted. The perception that the children had their own body and genitalia, according to the mothers, did not appear differentiated for $\mathrm{C} 4, \mathrm{C} 5$, and $\mathrm{C} 7$. The others had a negative perception of the body/genitalia, whether due to the excessive burden of feeling ashamed of the development of breasts, or for having a small penis and needing to sit down to urinate. Mothers M1, M2, M3, and M6 related not being aware of their child's feelings regarding their genitalia.

The others indicated, through their direct observations regarding the embarrassment exhibited by their child, or their own comments about the child, that $\mathrm{C} 1, \mathrm{C} 2, \mathrm{C} 4$ and $\mathrm{C} 5$ were aware of their differences when compared to cousins or siblings. Some questions that arose from this differentiated perception of the genitalia were in regard to the differences between male and female genitalia (C2 and C4). Others were in relation to the differences in genitalia within the same gender, such as the size of the penis, the absence of one of the testicles, or the position taken to urinate. Revelation of the diagnosis to the child was not always related to their questioning about their own genitalia or that of other children. Among the children who were aware of their diagnosis $(\mathrm{C} 2$, C4, C5 and C6), only C4 mentioned the matter to another person (his aunt). Mothers M4 and M7 said they had not heard negative comments from others about the body or genitalia of the child. M6 reported the negative perception by other children of her child, wich showed her concern about the consequences of such comments, such as feelings of inferiority influencing low self-esteem.

According to the mothers, all of the children appeared to have a gender identity corresponding to the assigned sex of the child. Only M3 confirmed that her child did not adapt to the assigned gender, but that the child felt satisfied with her body because it was similar to a boy's body. M2 related that her child, stated, just one time, that she would like to be a boy to be able to play in the street. Mothers M3 and M5 related that their children enjoyed activities related to the masculine gender role, but confirmed, at the same time, that they did not desire to be of the opposite sex. The children's preferred toys and games were, for four of the children, those typically associated with their gender (M1, M4, M6 and M7), while $\mathrm{C} 2, \mathrm{C} 3$ and C5 preferred those typically associated with the opposite sex. Most of the children, except $\mathrm{C} 1$ and $\mathrm{C} 4$, were also interested in games and toys normally open to both genders, such as playing volleyball, tag, hide-n-seek, and video games. In games, C1, C2, C4 and C7 assumed roles corresponding to the assigned gender. Thus, when they played "house", C1, C2 and C7 were mothers, daughters or nursed their dolls, while $\mathrm{C} 4$ was father, husband or son.

Mothers M2, M3, M4, M5 and M6 said that their children liked to perform household chores, assisting the mother in her housekeeping. According to M4 and M6, gender roles in their families aren't rigid, and the child may perform tasks considered "feminine" without compromising their gender identity. M7 said that her daughter did not like this kind of activity, and preferred to help the father when he was home. All of the mothers stated that their children preferred to play alone, and, at some times, preferred to be in groups. When they were among other children, they preferred to involve themselves with friends of various ages. Most of the children preferred to be grouped with other children of the same gender, however there was no rigidity as far as this choice.

The parents of the FPH children in this study did not want their children to exhibit behavior and preferences considered appropriate to the masculine gender. Practices such as imposing participation in physical activities like ballet, or the use of specifically feminine clothing, even when against the child's preference, and discussion of punishment for inappropriate behavior, were all behaviors observed in parents of these children.

With respect to the execution of "feminine" tasks on the part of the boys, it was necessary, first, to analyze the parents' attitudes in relation to stereotypical gender roles, as well as the significance attributed to masculine and feminine identity. In this sense, the mothers taught the boys to cooperate in domestic activities, without attributing the concept or significance of this work to one or the other gender. These mothers also informed their children regarding their condition, clarifying doubts and questions related to sex, gender, and intersexuality

However, as mentioned above, these families had similar characteristics in relation to the pattern of communication and interaction established in the intra- and extra-familiar sphere. Thus, as preconception is an important parameter influencing the opinion of parents in regard to sexual assignment, a tendency towards social isolation can be noted, such that issues and feelings brought up by questions of intersexuality remain restricted within the family context, thus being rarely, or almost never, shared with other persons.

For families that demonstrated a more rigid pattern, the condition of intersexuality is known only by the couple. In families that maintain a dialog with the children regarding their condition, discussion is usually educational and prescriptive, and limited to information and guidance.

The borders of the family group in relation to the social medium appear barely permeable. It would be legitimate to bring up the notion that due to the condition of secrecy associated with intersexuality, these groups tend to turn inward on themselves, to the detriment of exchange with other social groups. This, eventually, may constitute an obstacle to the development of the family, as well as each of its members, and, above all, of the intersexual child. In this way, a more rigid control over social relationships, bringing the mother to be cautious regarding friendships for the child, often restricting the child to the family circle, is justified by the veiled concern that their child will be the 
target of ridicule. Other mothers were concerned about preparing their children for possible situations in which they might be exposed to comments from other children. This strategy seems to be more appropriate to free the child to establish social ties, at the same time that they maintain the child informed about their condition.

The influence of social pressures leads to behaviors such as hiding the problem in an attempt to protect the child from preconceptions about the issue. It appears that the families that seek to obtain the most information about the condition, eliminating their doubts, share the idea of autonomy of the individual in decisions regarding treatment, and more often appear to expect favorable results from treatment. The parents also emphasize the importance of the family and the child receiving psychological counseling, especially when new surgeries have been recommended.

Lack of dialog within the family makes it difficult to understand how the child perceives him/herself and others, while over-protection is related to control over friendships and games. In this way, fear that the child may behave in ways outside of the accepted stereotypes, an exaggerated attitude of protection, and preconceptions and misconceptions about the process of communication can cause the parents to restrict the child's social contact, interfering with the child's choice of friends, toys and games. The parents may, for example, encourage the child to associate with other children of the same gender, favoring identification and imitation on the part of the intersexual child, or, on the contrary, they may hinder the child from associating with children that they judge to be inappropriate role models. The same occurs in relation to toys and games, which are chosen by the parents according to criteria of appropriateness for their child's gender.

Another difficulty these families face is the insecurity caused by the decision the parents have made regarding their child's gender assignment. This insecurity with respect to the responsibility for making such a decision for someone else is also experienced by the team which provides the diagnosis and treatment. However, the health professional, upon adopting the practice of sexual assignment with aesthetic surgery within the first years of life, in some ways delegates responsibility for the adaptation to the parents. That is, the health team decides the gender in which the child should be brought up, but the parents are given the responsibility for the success or failure of this determination.

\section{Final Considerations}

For the families involved, living with the stigma of intersexuality means living constantly in crisis in their system. Difficulties in doctor-patient communications, which lead to misunderstanding of the diagnosis and prognosis, as well as frequent surgical operations, create uncertainty with respect to child's adaptation to the assigned gender, and constitute stressful factors for the family system. At each stage of the life of the individual and the family, new symptoms and malfunctions arise, affecting the balance of the system. Thus, while the child is still an infant, concern over the child's gender assignment is the primary concern. During infancy, parenting styles are discussed, such as transmission of values and maintenance of behaviors appropriate to the initially established gender. During adolescence, concern over the influence of pubescent hormones and their influence on the continuity, or lack thereof, in the development of the assigned gender are the main emphasis. Questions about revealing the diagnosis to the child, sexual orientation, appearance of external genitalia, "competence" for sexual relations, and fertility continually create family stresses until adult life.

The families believe, in most cases, that the genetic error was caused by one of the parents, and thus live with guilt over the child's suffering. Additionally, they live in fear that they have made the wrong choice for the child's gender.

It is apparent that families with an intersexual child generally tend to attribute an essentially negative significance to the intersexual condition, characterized in part by the difficulties experienced beginning from the time of the diagnosis and lasting throughout the child's life. Among the difficulties, the most important are related to lack of information, which generates doubts and uncertainty regarding the possibility of future sexual re-assignment. Often these families are excessively worried about the possibility of a sex-change, reflected in the constant attention to the expression of behaviors and preferences that they consider inappropriate for the child's gender. Such preoccupation also represents an inhibiting factor on favorable expectations for the child's future.

For the families in the study, intersexuality (independent of the specific diagnosis, TH, MPH or FPH), is perceived as a serious illness and permanent threat for the family, despite the therapeutic options. It is surprising to find that the strategies for facing the dilemmas and difficulties of the family of a child with ambiguous genitalia are similar to the characteristics of families dealing with chronic illnesses.

Further study is still needed to contribute to a better understanding of the experience of the intersexual condition, reconfiguring the negative values still attributed by today's society and that reflect on the family. Additionally, it is essential that health professionals propose the creation of new possibilities for facing these issues together with the family, in such a way that the subject may be seen as an agent for change, with conditions for expression of feelings and ideas. The family, in turn, should reorganize itself as a systemic model of competence, transforming the model of fear and guilt.

The words of one of the mothers from this study clearly express the necessity for investment and education in this area, not only from the technical/instrumental perspective, but, above all, interactional: 
When the doctor spoke ... I felt as though I were outside myself ... it was like a shock, and more than a little disappointment, knowing that I had a child without knowing what it would live as, and, even more, because I was already seeing the result with my husband at my side...he had already panicked...My family, which was just starting out, had just come to an end... (M6).

In conclusion, continuous and specialized psychological support offered to the family, the child, and to the medical team constitutes an indispensable strategy for an approach that aims to ensure quality of life in intersexuality.

\section{References}

Bussey, K., \& Bandura, A. (1999). Social cognitive theory of gender development and differentiation. Psychological Review, 106, 676-713.

Colapinto, J. (2001). Sexo trocado: a história real do menino que criaram como menina. São Paulo: Ediouro.

Diamond, M. (1996). Prenatal predisposition and the clinical management of some pediatric conditions. Journal of Sex \& Marital Therapy, 22, 139-147.

Diamond, M. (1997). Sexual identity and sexual orientation in children with traumatized or ambiguous genitalia. Journal of Sex Research, 34, 199-211.

Diamond, M. (2004). Sex, gender, and identity over the years: A changing perspective. Child and Adolescent Psychiatric Clinics of North America, 13, 591-607.

Diamond, M. (2006). Biased-interaction theory of psychosexual development: How does one know if he is male or female? Sex Roles, 55, 589-600.

Diamond, M., \& Beh, H. G. (2005). The right to be wrong. Sex and gender decisions. Intersex \& Ethics, 103-113.

Diamond, M., \& Sigmundson, H. K. (1997a). Sex reassignment at birth: Long-term review and clinical implications. Archive of Pediatric and Adolescent Medicine, 151, 298-304.

Diamond, M., \& Sigmundson, H. K. (1997b). Management of intersexuality: Guidelines for dealing with persons with ambiguous genitalia. Archive of Pediatric and Adolescent Medicine, 151, 1046-1050.

Guerra-Júnior, G. (2002). Hermafroditismo verdadeiro. In A. T. Maciel-Guerra \& G. Guerra-Júnior (Eds.), Menino ou Menina? Os Distúrbios da Diferenciação do Sexo (pp. 53-57). São Paulo: Editora Manole.

Hester, J. D. (2004). Intersex(es) and informed consent: How physicians' rhetoric constrains choice. Theoretical Medicine, 25, 21-49.

Holmes, M. (2002). Rethinking the meaning and management of intersexuality. Sexualities, 5, 159-180.

Maciel-Guerra, A. T., \& Guerra-Júnior, G. (2002a). Ambigüidade genital: classificação. In A. T. Maciel-Guerra \& G. GuerraJúnior (Eds.), Menino ou menina? Os distúrbios da diferenciação do sexo (pp. 31-36). São Paulo: Editora Manole.
Maciel-Guerra, A. T., \& Guerra-Júnior, G. (2002b). Diagnóstico das ambigüidades genitais: Avaliações clínica e laboratorial. In A. T. Maciel-Guerra \& G. Guerra-Júnior (Eds.), Menino ou menina? Os distúrbios da diferenciação do sexo (pp. 165-173). São Paulo: Editora Manole.

Martin, C. L., Ruble, D. N., \& Szkrybalo, J. (2002). Cognitive theories of early gender development. Psychological Bulletin, 128, 903-933.

Meyer-Balhburg, H. F. L. (1999). Gender assignment and reassignment in 46, XY pseudohermaphroditism and related conditions. Journal of Clinical Endocrinology and Metabolism, 84, 3455-3458.

Money, J. (1994a). The concept of gender identity disorder in childhood and adolescence after 39 years. Journal of Sex \& Marital Therapy, 20, 163-177.

Money, J. (1994b). Biographies of gender and hermaphroditism in paired comparisions. Amsterdam: Elsevier.

Money, J., Hampson, J. G., \& Hampson, J. L. (1955). An examination of some basic concepts: The evidence of human hermaphroditism. Bulletin of Johns Hopkins Hospital, 97, 301-319.

Moore, K.L., \& Persaud, T.V.N. (1998). The developing human: Clinically oriented embryology ( $6^{\text {th }}$ ed.). Philadelphia: Saunders. [Translation: Embriologia básica. Rio de Janeiro: Guanabara Koogan, 2000.]

Reiner, W. G. (1997a). To be male or female: That is the question. Archive of Pediatric and Adolescent Medicine, 151, 224-225.

Reiner, W. G. (1997b). Sex assignment in the neonate with intersex or inadequate genitalia. Archive of Pediatric and Adolescent Medicine, 151, 1044-1045.

Santos, M. M. R. (2000). Desenvolvimento da identidade de gênero em crianças com diagnóstico de intersexo: Casos específicos de hermafroditismo verdadeiro, pseudo-hermafroditismo masculino e feminino. Master's dissertation, University of Brasília.

Santos, M. M. R., \& Araujo, T. C. C. F. (2003). A clínica da intersexualidade e seus desafios para os profissionais de saúde. Psicologia: Ciência e Profissão, 23, 26-33.

Slijper, F. M. E., Drop, S. L. S., Molenaar, J. C., \& De Muinck Keizer-Schrama, S. M. P. F. (1998). Long-term psychological evaluation of intersex children. Archives of Sexual Behavior, 27, 125-144.

Valsiner, J., Branco, A. U., \& Dantas, C. M. (1997). Co-construction of human development: Heterogeneity within parental belief. In J. E. Grusec \& L. Kuczynski (Eds.), Parenting and children's internalization of values: A handbook of contemporary theory (pp. 283-304). New York: Wiley.

Walsh, F. \& McGoldrick, M. (2004). Living beyond loss: Death and the family ( $2^{\text {nd }}$ ed.). New York: Norton. [Translation: Morte na família: Sobrevivendo às perdas. Porto Alegre: Artes Médicas, 1998.]

Zucker, K. J. (1999). Intersexuality and gender identity differentiation. Annual Review of Sex Research, 10, 1-69.

Received November 18, 2006 Revision received October 1, 2007 Acepted November 23, 2007 